Accepted version of Boud, D. and Costley, C. (2007). From project supervision to advising: new conceptions of the practice, Innovations in Education and Teaching International, 44, 2, 119-130.

\title{
From project supervision to advising: new conceptions of the practice
}

\author{
David Boud, University of Technology, Sydney \\ Carol Costley, Middlesex University
}

\begin{abstract}
Project work has been a common feature of undergraduate degree programmes for many years. While it has been named in a variety of ways, it typically involves students undertaking a substantial learning activity that is partly self-initiated and managed. More recently, programmes organised around the idea of work-based learning partnerships have emerged. These can be regarded as programmes that rely on significant amounts of work-based project work. This paper examines the implications of practices in these new programmes for project advising more generally. It argues that the conception of the role of academics in project work needs to change from one focused on project supervision to one of learning adviser. It identifies key features of this practice and discusses differences in advising from one context to another. It suggests that the activities in which academics engage need to be reappraised and that the skills and knowledge of those acting in the role of adviser be extended.
\end{abstract}

What was once the simple notion of a student project has broadened considerably to encompass a wide range of purposes and activities. At the same time there has been a move away from conventionally located disciplinary student work towards highly contextualised tasks that simultaneously relate to the needs of learners and engage with the world outside universities. Financial pressures on courses, and in particular on project activities, have brought about a necessity to rethink learning and teaching practices. These changes are influencing academics who now find themselves subject to new educational and vocational expectations. This re-appraisal of their role is often occurring alongside a reduction in the resources available for each student. The aim of this paper is to explore the role of the academic adviser supporting projects in undergraduate and other coursework programmes in these new conditions. 
Almost all degree programmes now include at least one project or series of projects. Commonly, students have an individual link with a staff member. However, very little scrutiny has been given to the role of academics in this context. This is in contrast to research degrees in which there has been a recent flourishing of interest in supervision (e.g. Pearson and Brew, 2002; Beasley, 2005; Boud and Lee 2005). A major difference is that research degrees, which have been predominantly post-graduate, have a specific focus in generating research training and research outcomes whereas other kinds of project have a much wider range of learning, rather than research, outcomes.

Our interest in project work here arose from involvement in the area of work-based learning (WBL) partnerships that are primarily located in work and students are typically employed full-time before and during their course. Most radically, they pursue a curriculum driven by the exigencies of work rather than by primarily academic concerns (Boud and Solomon, 2001). WBL programmes place a special demand on academic staff as it takes them beyond their familiar teaching role.

Our naming of these activities as project advising rather than supervision is deliberate. Supervision is a term typically used in postgraduate research degrees in universities following the British tradition. It suggests a particular form of relationship between staff member and student that is often intense and extended. It also has connotations of direct oversight and 'top-down' power relations between supervisor and supervisee.

The purpose of the paper is to suggest that while the reduction of resources for teaching and learning may have stimulated the growth of new practices, for these to be consolidated and developed in pedagogically fruitful ways, a reorientation from supervisor to adviser role in project work is needed. The paper draws on a study of project advising in work-based learning, but it is primarily an argument for new ways of thinking about the role of those who support project work. Data had been collected by the first author as part of a small-scale investigation of the skills and knowledge base of WBL advisers. From two workshop sessions with experienced advisers conducted in Australia and one in the UK, five constituents of the conceptual knowledge and skill base needed for the advising of work-based projects were identified from oral and written responses, The workshops aimed to identify the knowledge and skills base for advising in work-based programmes. They focused on emerging features of supervision prompted by the relationships that necessarily prevail in work-based contexts. Phase two of the research involved both authors sharing the data with a team of experienced WBL advisers in a UK university. The differences between typical student projects and WBL projects 
were identified and some differences between supervision and advisory practices were analysed and discussed. The paper starts with a discussion of earlier studies of independent study and negotiated learning and proceeds to focus on what can be taken from work-based learning. The outcomes of the analysis are then discussed in terms of their implications for project advising.

\section{What is a Project?}

The literature on project work encompasses anything from a small project within a course module to programmes of study based on project work (Adderley et al 1975, Olesen \& Jensen 1999). The range and type of project used in undergraduate courses is diverse and may go under many names: extended assignment, major report, mini-thesis, critical summary, long essay and so on. One characteristic they share is that they are extended pieces of independent work carried out over many weeks, often a whole semester. There is normally a deadline for submission within the semester of study, though in a few cases this may extend over a longer period. There is sometimes considerable scope for students to influence the direction of the work, but at undergraduate level the project topic is often either given or limited to closely defined parameters.

Unfortunately, most of the literature on project supervision has been concerned with postgraduates and most of the recent literature on undergraduate projects focuses particularly on assessment rather than the processes of advising students (e.g. Heylings \& Tariq 2001, Orsmond et al 2004). From earlier work, there is some evidence that there may be differences between the ways projects have been supervised in different disciplines. For example, a tendency has been noted for arts and humanities subjects to require students to take greater responsibility for their projects whereas in the sciences tutors are often more directive (Armstrong \& Shenker, 1983). Traditionally, the power of the disciplines, through the supervisor's greater understanding of the knowledge content of the project, has influenced control of the project to be located with the supervisor yet there is little in the literature that critiques this position. That there is little critical or recent literature about most aspects of project supervision is surprising given the pervasiveness of the practice.

\section{Particular orientations to and kinds of project work}

It is possible to plot part of the history of interest in project work through practices labelled independent study, self-directed and negotiated learning as these are represented more fully in the literature than disciplinary practices. These have drawn on a humanistic 
educational tradition that emphasised students taking responsibility for their own learning, choosing and initiating their study (Boud, 2006).

\section{Independent Study}

One reason for the growth of project work has been the drive towards developing abilities in undergraduates that orient them towards employability or graduateness (Osborne et al, 1998) and develop what has become known as key or transferable skills to foster independent learners able to apply knowledge and become, or enhance their capability as, professional practitioners (Stephenson, 1988) and self-manage their learning (Stephenson 1998). There was a move away from traditional, usually small, student projects in specialist subject areas. A supervisor would be appointed and it was left to the individual student and tutor to arrange tutorial sessions. As this model, inherited from the postgraduate research curriculum, began to change, studies indicated that many of the accepted elements of supervision were being contested, for example in the way a time allocation was made for supervision, how the pace of supervision was determined and the availability of the tutor (Armstrong, 1997; Marshall, 1999). Armstrong (1997) also advocated structure, control and consistency that would provide students with short but regular tutorials and combat any 'sense of isolation' in individual project work.

The focus became autonomy for students and this meant a less directive stance for the supervisor (Armstrong \& Shenker, 1983) and an ability to act in a more supporting and affective role using interpersonal skills (Marshall, 1999). McMichael (1992), for example, identified an 'enabling approach' in which students own their projects and are encouraged to emphasise their personal and organisational qualities.

Cuthbert (2001) identified a set of dimensions within projects consistent with an independent learning approach. She focused on the structure and responsibility for projects in independent learning: they are likely to be chosen fully by the student; the source of the project material is likely to be located by the student rather than supplied by the tutor; the methodological approach is chosen by the student rather than prescribed by the tutor; and the supervisor guides the student rather than proposing the project's direction. The academic orientation of the project in independent study is often a real world issue rather than an academic topic and it is likely to be interdisciplinary. Independent study is likely to contain explicit skills promotion as opposed to minimal emphasis on skills and there will be a clearly defined planning period in contrast to a 
limited explicit planning time. Finally in independent study the project component is likely to be large and be a feature of the course.

\section{Negotiated learning}

In order to accommodate independent projects within conventional course structures, basic frameworks are established around what is termed a learning contract or learning agreement. These commonly take the form of open templates in which students propose goals and objectives, learning activities and assessment processes (Anderson, Boud \& Sampson, 1996). Plans are negotiated with a staff member and approved by a university panel or individual as appropriate in content.

The place of advising in this is threefold. First, to orient students to create an environment in which they are comfortable with the idea and resourced to identify projects and develop plans. Second, to undertake one-to-one negotiation of the plan with the student. Thirdly, to assist the student in judging whether the plan is complete. The entire pool of supervisors (and other academics and practitioners) could provide a resource of expertise that students could draw upon for specific needs in the execution of any particular plan. While study of such practices has been undertaken and they have been codified (e.g. Anderson et al 1996), there has been relatively little focus on the specific role of advisers. The literature has not addressed their role, which is inevitably configured by the system in which they operate. However, in the negotiated learning tradition, the development and recording of a plan, that is, the practice of the student, has been more carefully specified than hitherto in independent study.

There has been a tendency to use such negotiated learning when dealing with students who were engaged in projects outside the university (rather than ones that could be undertaken exclusively in the library or laboratory). However, its practice was co-opted and extended with the introduction of more radical forms of WBL in the 1990s.

\section{Work-based learning}

Conventionally, individuals undertake projects in academic contexts, but increasingly new contexts for learning have brought about involvement with other people and settings outside academia. Universities are changing programmes to include opportunities for group projects, accrediting prior learning, mentoring, coaching, consultancy and assessment from individuals who are not academics in community or work settings. In many respects these new contexts have inevitably shifted supervision to more of an 
advisory role and away from a supervisory one resulting in a less hierarchical student/adviser relationship. Learners are now more likely to receive support from their work settings and have a more learner-managed role in project work that emanates from their contextualised practice. Moreover, the move to a greater diversity of learning activities and away from conventionally defined disciplinary work has included a greater involvement in workplaces. Whilst direct supervision of students may have lessened, the adviser plays a differing, wider and sometimes more facilitative role.

We specifically focus on WBL to examine the adviser role in more depth. WBL partnerships in the UK came about following government-funded initiatives in the early 1990s. The practice-based imperatives of WBL are also embraced by moves to widen participation in higher education and in particular a movement to focus learning in the 'real world' projects of individuals and groups doing 'real time' work, paid or unpaid (Boud \& Solomon 2001).

Table I below uses ideal types to illustrate some broad differences between work-based and other more traditional student project work. The implications of work-based projects on advising students are then discussed. 
Table I. Some common differences between work-based projects and other student projects

\begin{tabular}{|l|l|}
\hline WBL project & Typical student project \\
\hline Student is insider to problem/context & Student is outsider \\
\hline Focus on work and learning for work & Focus on learning disciplinary knowledge \\
\hline Setting defines what is required (in part) & $\begin{array}{l}\text { Greater emphasis on supervisor to define } \\
\text { standards }\end{array}$ \\
\hline Practice drives use of theory & Theory privileged over practice typically \\
\hline $\begin{array}{l}\text { Primary abilities to be fostered: reflexivity, } \\
\text { development }\end{array}$ & $\begin{array}{l}\text { Variable abilities to be fostered, often } \\
\text { critique and analysis }\end{array}$ \\
\hline $\begin{array}{l}\text { Draws on wide range of resources/ support } \\
\text { within work organisation }\end{array}$ & $\begin{array}{l}\text { Draws on resources/ support within } \\
\text { educational institution }\end{array}$ \\
\hline Embraces knowledge-in-practice & $\begin{array}{l}\text { Knowledge-in-practice limited or non- } \\
\text { existent }\end{array}$ \\
\hline Time-limited by real world constraints & $\begin{array}{l}\text { Time-limited by timetable and university } \\
\text { deadlines }\end{array}$ \\
\hline $\begin{array}{l}\text { Driven by the exigencies of work usually } \\
\text { interpreted widely }\end{array}$ & $\begin{array}{l}\text { Driven by specified learning outcomes and } \\
\text { interests of student and adviser }\end{array}$ \\
\hline $\begin{array}{l}\text { Paradigm/ methodology not necessarily } \\
\text { evident }\end{array}$ & $\begin{array}{l}\text { Works within defined paradigm/ } \\
\text { methodology }\end{array}$ \\
\hline $\begin{array}{l}\text { Outcomes- mix of pragmatic/organisational } \\
\text { and academic. Applied in real settings }\end{array}$ & $\begin{array}{l}\text { Outcomes predominantly academic. Not } \\
\text { normally applied in real settings }\end{array}$ \\
\hline $\begin{array}{l}\text { Student knows about existing context and } \\
\text { knowledge boundaries }\end{array}$ & $\begin{array}{l}\text { 'Supervisor' has knowledge that is passed } \\
\text { on to student }\end{array}$ \\
\hline
\end{tabular}

WBL adds to Cuthbert's (2001) analysis of independent projects, the change in the setting of the learner from classroom to workplace. Laycock (2003) for example, considers that emerging best practice for work-related projects involves the workplace as the situational context of learning. WBL may include whole programmes of study that are work-based or specific modules on a traditional programme that introduce work-based activities. These activities often include projects undertaken through work experience, work shadowing, mentoring schemes or the conventional placement period.

While there are many varieties of work-related, work-place or work-based learning (the terms are unfortunately used interchangeably) in higher education, we focus on the approach that operates for existing workers who wish to undertake higher education study drawing on their own working environment (Garnett 2005). These programmes take student projects firmly outside the university, acknowledge the student's existing expertise and are predominantly self-directed. WBL partnerships often involve students negotiating an entire programme of study utilising work (rather than existing courses) as 
the curriculum. The programmes are typically individually negotiated. However, in these cases the learning agreement is normally a three-way one with a representative of the work organisation or professional area as the third party. In this way the learning activity is intended to be of benefit not only to the student/worker, but the organisation and/or community of which they are part.

The situatedness of work-based projects creates challenges to the adviser over and beyond that found in other negotiated programmes. Additionally, the learning undertaken does not normally fit within the subject discipline background of the adviser, and also, it often does not fit within any existing university discipline. The focus is commonly on transdisciplinary knowledge that is practice-based so the conditions in which knowledge is produced are different from those found within universities (Gibbons et al 1994). Knowledge itself that appears in work-based projects and is sometimes contested (Usher \& Solomon 1999) is an important aspect of power. This shift in knowledge content and approach to knowledge has implications for the power relationship between student and adviser.

\section{Advising within WBL}

These challenges prompted the first phase of the research as discussed earlier in which the following five clusters of knowledge and skill- base were identified as desirable to be able to advise effectively in the emerging environment of WBL. In some cases, these were aspirations rather than existing features.

\section{Knowledge of work and context}

Advisers need to play a role in recognising knowledge emanating outside the university and be sensitive to the exigencies of work and its influence on learners and learning. Table I draws attention to the positioning of students and advisers in terms of both the project location (outside the university) and the real world context that includes the status of the student and status of the project work. Arising from these differing contexts, advisers need to recognise that their students are rooted in their own particular context that includes the politics of organisations, the wider dimensions of organisational learning and the social dimensions of work, rather than in disciplinary knowledge. Students have insider knowledge and are primarily concerned with professional practice. This rootedness in a particular context affirms students' positionality and relocates the adviser from a traditional position of authority in the subject. The adviser needs expertise relating to work context. For example, awareness of and ability to intervene in situations in which 
learning is constrained by workplace values and practices, including mediation with work supervisors; acknowledgement and representation of work-related learning outcomes which may not be able to be appropriately translated into academic conventions; theorisation of work, organisations and the management of change and ability to connect this with learning projects.

\section{Learning consultancy skills}

As well as the traditional range of learning consultancy skills and an awareness of the need to refer to other academics as appropriate, work-based project advisers need to enable students to see learning opportunities in their work and life. They need an understanding and knowledge of the way work-based projects can be constructed and evolved, how to negotiate learner-managed learning plans for complex settings by providing suitable forms of support to learners including assistance in managing challenges to identity, the dual expectations of academy and workplace and setting up learning pathways. These abilities include how to link conceptual understanding of work with conceptual understanding of learning and the demystification of academic discourses.

Responsibility lies with the university adviser, the learner and if appropriate, the employer or sponsor to ensure that work-based projects are both purposeful and academic so they meet the requirements of higher education assessment standards, the personal and career aims of the learner, and the practical outcome-oriented needs of the organisation or other community of practice. In order to maintain quality and standards, academic advisers pay attention to the detail of operations and systems, ensure specific assessment criteria and student outcomes meet university requirements, draw on the expertise of other professionals and enter into current debates in higher education about the definition of practice-based (high level) knowledge, values and ethics. The pedagogical understanding that is needed by the project adviser therefore relates to adults' learning and in particular to acknowledging learners' existing experience and expertise. The sharing of expertise has an impact upon the power relationship between student and adviser requiring the adviser to listen and take account of the student's current knowledge and position.

\section{Transdisciplinarity awareness}

WBL offers new and challenging transdisciplinary learning opportunities that can develop students further. Within the university the development of cross-disciplinary 
frameworks for curriculum and learning should include the discernment of variation in conceptual knowledge (Bowden \& Marton 1998). Advisers also need an awareness of the strengths and limitations of conceptualisations of disciplinary knowledge that constitute themselves in a work-based situation. They need to find strategies for how to engage with communities of practice outside of the academic sphere. This involves understanding and knowledge in an epistemology of practice where knowledge is created and used rather than codified. Many professionals have an understanding of this kind of knowledge recognition, creation and use in their continuing development; however, project advisers need to formalise this thinking in order to assist their students. They can do so by developing an ability to interpret the language of academia and workplaces in the context of learner needs and expectations. They need facility in talking and writing about work as learning, experience as knowledge and an awareness of frameworks for the analysis of knowledge, organisations and learning, for example through systems thinking.

\section{Enquiry approaches}

Work-based projects are frequently concerned with development and change and the generation of new knowledge for practice and because of their practice-based orientation tend to differ significantly from more typical student projects c.f. Table I. Advisers have to steer students into producing a project that involves high level judgements and decision making that influences change in complex real life situations and from which students can enhance practice in their organisation or professional area c.f. Table II. Advisers therefore need expertise in the supervision of real time research and development projects. They need knowledge of practitioner-led research and development (Armsby \& Costley 2000) e.g. action learning; critical and co-operative enquiry; action research; soft systems, etc. and structuring of work-based project proposals.

Work-based projects require knowledge of enquiry generally, but also more specialised aspects, for example methodological approaches of development and systemic change, information and knowledge management strategies, knowledge of and strategies for accessing expertise in organisations, knowledge of ethical issues (Costley and Gibbs 2006) and other boundaries (social, commercial, political, etc) which may confront learners. 


\section{Reflexivity and reviewing skills}

Development through WBL happens within the requirements, criteria and quality mechanisms of the university. It needs a reflective and evaluative approach that involves analytic and theoretical reasoning. Advisers need knowledge of reflective practice (Schön 1976), reflexivity about one's own learning and the effects of personal learning history (one's own and others') on current conceptualisation and practice. These kinds of abilities involve strategies and practices for noticing, recording, interpreting and representing and development of peer learning strategies (face-to-face and electronic to support learning and aid reflection). They involve knowledge of self-assessment frameworks, forms of documenting and presenting learning outcomes, levels and standards of achievement and ways of operationalising them and relating them to learning outcomes and fitness for purpose within organisations.

\section{Implications for project advising}

In phase two of the study a group of experienced WBL advisers examined data from phase one and concluded that the skills and knowledge of advisers in WBL courses are not necessarily the same as those needed in other conditions. Some of the differences between them were highlighted so that matters related more generally to project advising could be identified. Table II summarises major differences found between situations that are substantially work-based and those that are not. Many if not most examples of project work would fall between the two and the extent to which the features discussed below are pertinent in any given situation will vary. The features from our analysis that apply to project-advising are therefore context-specific. 
Table II. The advisory role in WBL projects and non-WBL projects: some frequently found differences

\begin{tabular}{|c|c|}
\hline WBL advising & Non-WBL advising \\
\hline $\begin{array}{l}\text { 3-way relationship: often mediated } \\
\text { between student, adviser, work supervisor }\end{array}$ & Direct 2-way relationship: Student, adviser \\
\hline $\begin{array}{l}\text { Commonly involves parties other than the } \\
\text { student, adviser and work supervisor }\end{array}$ & $\begin{array}{l}\text { Less common to involve parties other than } \\
\text { the student and adviser }\end{array}$ \\
\hline Multi-mode contact & Typically face-to-face \\
\hline Negotiation of topic and process & May be unilateral \\
\hline Plan negotiated at start & Plan is more often emergent \\
\hline Formalised 3 way learning agreement & Learning agreement not common \\
\hline May be assessed by practitioner & $\begin{array}{l}\text { Sometimes assessed by practitioners } \\
\text { (depends on context of project in course) }\end{array}$ \\
\hline $\begin{array}{l}\text { Products highly varied, but typically } \\
\text { include reflective component }\end{array}$ & $\begin{array}{l}\text { Conventional academic output: reports, etc, } \\
\text { may not include reflective component }\end{array}$ \\
\hline $\begin{array}{l}\text { Learner is an insider and expert in subject } \\
\text { area/context }\end{array}$ & 'Supervisor' expert in subject area/topic \\
\hline $\begin{array}{l}\text { Adviser expert in frameworks/levels of } \\
\text { achievement }\end{array}$ & $\begin{array}{l}\text { Framework/level of achievement pre- } \\
\text { defined for student }\end{array}$ \\
\hline $\begin{array}{l}\text { Adviser expert in epistemology of practice } \\
\text { (including linking knowledge) }\end{array}$ & $\begin{array}{l}\text { 'Supervisor' expert in epistemology of } \\
\text { discipline }\end{array}$ \\
\hline $\begin{array}{l}\text { Adviser and learner have distinct areas of } \\
\text { expertise }\end{array}$ & $\begin{array}{l}\text { 'Supervisor' and learner often in } \\
\text { relationship of authoritative power }\end{array}$ \\
\hline
\end{tabular}

The comparisons made in Table II point to some of the implications for project advising from the changes that have been occurring in WBL practice. We suggest that there is value in project advising taking up some of the features that have hitherto been mainly represented in WBL advising.

The development of the academic adviser role indicated in Table II has not only occurred because of new contexts but because of a growing awareness, of both the contributions that academic advisers can make, and the limits to their interventions. This has parallels in the wider project advising context where part of the change in role includes a shift from dependence on single supervision to accessing wider and distributed sources of support. As such there has been a decentring of the role of project adviser. Nevertheless, there is still a fundamental role that emphasises the total environment and general framework of projects. To this end advisers could benefit from an awareness of a range of 
working contexts and cultures to ensure that their advisees have the preparation, resources and self-monitoring strategies they need.

Advisory practices also vary greatly from the minimal - initial briefing and final marking of the completed product - to the extended-regular meetings throughout the period. For major projects such as those in final or honours year, explicit programme-wide guidelines are often made available. For other kinds of project the degree of explicitness about the processes involved is in the hands of the course coordinator or individual adviser.

The change in role may require advisers to help guide students into projects that have the propensity to bring about the kind of learning appropriate for them and their learning programme. For example, a good project for a work-based learner is one where the student can play a strategic role in the development of the project. In this case the student is the expert in the real life development of the project and the adviser is more mentor and facilitator than teacher. Specific guidance can be given in for example, structuring the project report, methodological approaches, and techniques of researching and developing.

It is not only a change in the specific tasks that advisers perform or knowledge they need to have that is changing; power relationships within the student/ adviser dynamic in all kinds of project work have been an important concept, especially within the now often hidden hierarchies contained in assumptions relating to gender, race and class (Hammick $\&$ Acker 1998). The power dynamic between adviser and student becomes more balanced, or perhaps more accurately, less imbalanced, when each offers expertise about the shaping of a work-based project. Advisers who are used to being 'the expert' may have difficulty in changing to this more equal student/adviser relationship. Differing contexts of learning may enable such pedagogical change but the academy still gives the grades and remains the final arbiter of knowledge claims. Advisers are still able to impact on the construction of meaning of student work especially at undergraduate level. This may be because the interpretation of any text is not objective or true but one of a plurality of interpretations constrained by discursive and material positioning of both student and adviser (Lea \& Street 1998) and this remains the case whatever the context for learning.

University structures themselves may not always be conducive to treating students as experts, independent learners or workers who enter the university with knowledge status. 
Change at the level of systems and structures within universities would support advisers to undertake their changed roles effectively.

While there are many features of the emerging role of project advising, and some of these will necessarily be contested and others will be inappropriate to a particular setting, it is possible to summarise some elements that have emerged from our discussions. See Table III.

Table III. Summary features of project advising

\begin{tabular}{|l|l|}
\hline Learner-focused & $\begin{array}{l}\text { An emphasis on the learning of the student } \\
\text { not primarily on the technical output of the } \\
\text { project }\end{array}$ \\
\hline Learner-managed & $\begin{array}{l}\text { Projects actively managed by students who } \\
\text { are equipped for this task through prior } \\
\text { coursework }\end{array}$ \\
\hline Adviser rather than supervisor & $\begin{array}{l}\text { Except when there are necessary } \\
\text { considerations of risk, students are not } \\
\text { directly supervised in the sense of close } \\
\text { monitoring of their work }\end{array}$ \\
\hline Shift to focus on total learning environment & $\begin{array}{l}\text { Expectations of both adviser and student } \\
\text { are made explicit and considered as part of } \\
\text { early engagement }\end{array}$ \\
\hline Acknowledges importance of context & $\begin{array}{l}\text { Not just on the expertise and resources of a } \\
\text { single staff member, but on the variety of } \\
\text { resources available, including other } \\
\text { students }\end{array}$ \\
\hline Active judgements & $\begin{array}{l}\text { Particularly the influences, opportunities } \\
\text { and constraints of the settings in which the } \\
\text { project is conducted }\end{array}$ \\
\hline & $\begin{array}{l}\text { Learners play a central role in identifying } \\
\text { and utilising criteria for judging } \\
\text { appropriate work }\end{array}$ \\
\hline
\end{tabular}

While we can benefit from examining experience of WBL advising we should be wary that the conditions are not the same in all contexts. Most significant are assumptions about student expertise. Clearly, students, by virtue of being students, are lacking in expertise of some kinds. The traditional model has been one in which knowledge and skills were directly fostered by the supervisor. That is no longer sustainable except in limited situations. To support project work now is to find ways of assisting students to develop the expertise needed in any given situation. While the adviser continues to have a role in this, learners need to be resourced and to resource themselves in a greater variety 
of ways. In this, there is little appropriate didactic role in transmitting knowledge. A major challenge is to find ways of representing and sharing some of the kinds of practicebased knowledge discussed here with learners without the activity turning into a new disciplinary curriculum.

Systems and strategies within universities may not always change quickly enough to serve different ways of working and new curricula but an effective system of undergraduate project advising within universities might at least address the points in Table III. A system for project advising itself could be couched within appropriate frameworks for guidance and advice that allows student autonomy and at the same time provides clarity to advisers about what is expected of them.

\section{Conclusion}

The creation of a rich and supportive learning environment within which students can manage their own learning, draw support from others and access the resources they need, can provide much of the pedagogical support required for project work. The adviser continues to play a vital but changed role that demands a wider more complex set of abilities and can ultimately identify when it is not being effective and act on this observation.

\section{References}

Adderley, K., Ashwin, C., Bradbury, P., Freeman, J., Goodlad, S., Greene, J., Jenkins, D. \& Uren, O. (1975) Project Methods in Higher Education. (London: Society for Research into Higher Education.)

Anderson, G., Boud, D. \& Sampson, J. (1996) Learning Contracts: A Practical Guide. (London: Kogan Page.)

Armsby, P \& Costley, C. (2000) Research driven projects, In Portwood, D. \& Costley, C. (Eds.) Work-Based Learning and the University: New Perspectives and Practices, SEDA Paper 109. (Birmingham: Staff and Educational Development Association).

Armstrong, S. (1997) Dissertation supervision: managing the student experience, in Armstrong, S., Thompson, G. \& Brown, S.. (Eds) Facing up to Radical Changes in Universities and Colleges. (London: Kogan Page.)

Armstrong, M. \& Shenker, V. (1983) The supervision of undergraduate research: student perceptions of the supervisor role. Studies in Higher Education, 8, 2, 177-188 Beasley, N. (2005) A Handbook for Doctoral Supervisors. (London: Routledge.) 
Boud, D. (2006) Aren't we all learner-centred now? the bittersweet flavour of success. In Ashwin, P. (Ed.). Changing Higher Education: The Development of Learning and Teaching. (London: Routledge). 19-32.

Boud, D. \& Solomon, N. (2001) Work-Based Learning: A New Higher Education? (Buckingham: SRHE \& Open University Press.)

Boud, D. (2001) Creating a work-based curriculum. In Boud, D. \& Solomon, N. WorkBased Learning: A New Higher Education? (Buckingham: SRHE \& Open University Press.)

Boud, D. \& Lee, A. (2005) 'Peer learning' as pedagogic discourse for research education, Studies in Higher Education, 30, 5, 501-516.

Boud, D., Cohen, R. \& Sampson, J. (Eds.) (2001) Peer Learning in Higher Education: Learning from and with each other. (London: Kogan Page.)

Bowden, J \& Marton, F. (1998) The University of Learning: Beyond Quality and Competence in Higher Education. (London: Kogan Page.)

Cook, M.C.F. (1980) The role of the academic supervisor for undergraduate presentations, Studies in Higher Education 5, 2, 173-182.

Costley, C. \& Gibbs, P. (2006) Researching others: care as an ethic for practitioner researchers, Studies in Higher Education, 31, 1, 89-98

Cuthbert, K. (2001) Independent study and project work: continuities or discontinuities, Teaching in Higher Education, 6, 1, 69-84.

Garnett, J. (2005) University work-based learning and the knowledge driven project. In B.Workman \& K. Rounce (Eds)Work-based Learning in Health: Innovations and Applications, (London, Kingsham Press.)

Gibbons, M., Limoges, C., Nowotny, H., Schwartzman, S., Scott, P., \& Trow, M. (1994)

The New Production of Knowledge: The Dynamics of Science and Research in Contemporary Societies, (London: Sage.

Hammick, M. \& Acker, S. (1998) Undergraduate research supervision: a gender analysis. Studies in Higher Education 23, 3, 335-347

Heylings, D. J. A. \& Tariq, V. N. (2001) Reflection and feedback on learning: a strategy for undergraduate research project work, Assessment and Evaluation in Higher Education, 26, 2, 153-164.

Laycock, M. (2003) Notes for Guidance on Work-Related Learning (London, Southern England Consortium for Credit Accumulation and Transfer.) 
Lea, M. \& Street, B. (1998) Student writing in higher education: an academic literacies approach. Studies in Higher Education, 23, 2, 157-172

Marshall, S (1999) Supervising projects and dissertations, In Fry, H., Ketteridge, S. \& Marshall. S. (Eds) A Handbook for Teaching and Learning in Higher Education; Enhancing Academic Practice 108-119 (London, Kogan Page)

McMichael, P. (1992) Tales of the unexpected; supervisors' and students' perspectives on short-term projects and dissertations, Educational Studies, 18, 3, 299-310.

Olesen, H. S. \& Jensen, J. H. (Eds.) (1999) Project Studies: A Late Modern University Reform? (Roskilde: Roskilde University Press.)

Orsmond, P., Merry, S. \& Reiling, K. (2004) Undergraduate project work: can directed tutor support enhance skills development. Assessment and Evaluation in Higher Education, 29, 5, 625-642

Osborne, C., Davis, J. \& Garnett, J. (1998) Guiding the learner to the centre of the stakeholder curriculum. In Stephenson, J. \& Yorke, M. (Eds) Capability and Quality in Higher Education, (London: Kogan Page.)

Pearson, M. (2004) Changing contexts for research education: implications for supervision development. In Green, P. (Ed.) Postgraduate Research Supervision: Contexts and processes, theories and practices. (Melbourne: RMIT Press.)

Pearson, M. \& Brew, A. (2002) Research training and supervision development. Studies in Higher Education, 27, 2, 135-150.

Stephenson, J. (1988) Learner responsibility: linking progressive education to the economy, New Era, 69, 3, 85-88.

Stephenson, J, (1998) Supporting student autonomy in learning, in Stephenson, J. and Yorke, M., Capability and Quality in Higher Education, (London: Kogan Page)

Usher, R. \& Solomon, N. (1999) Experiential learning and the shaping of subjectivity in the workplace. Studies in the Education of Adults, 31, 155-163. 